\title{
Kimya Öğretmeni Adaylarının Asit-Baz Konu Alanıyla İlgili Bilişsel Yapıları
}

\author{
DOI: 10.26466/opus. 800862 \\ * \\ Ayşegül Derman* - Figen Günes ** \\ ${ }^{*}$ Doç.Dr., Necmettin Erbakan Üniversitesi \\ E-Posta: aderman1977@gmail.com \\ ORCID: 0000-0003-3856-1017 \\ ** Y.L, Necmettin Erbakan Üniversitesi \\ E-Posta: figengunes88@gmail.com \\ ORCID: 0000-0001-5216-8428
}

\section{Öz}

Bu araştırmanın amacı, kimya öğretmeni adaylarının asit-baz konu alanıyla ilgili bilişsel yapılarının betimsel ve yapısal özelliklerinin belirlenmesidir. Araştırmanın çalışma grubunu 2018-2019 akademik yılında lisans ve yüksek lisans düzeyinde öğrenimlerine devam etmekte olan 29 kimya öğretmeni adayı oluşturmaktadır. Araştırma kimya öğretmeni adaylarının asit-baz konu alanıyla ilgili bilişsel yapılarını betimsel ve yapısal olarak detaylı bir biçimde ele alması bakımından durum çalışmasıdır. Verilerin toplanmasında kelime ilişkilendirme testi ve serbest yazma tekniği kullanıldı. Verileri analiz etmek için içerik analizi tekniği kullanıldı. Araştırmada elde edilen bulgulara göre, kimya öğretmeni adaylarının asit-baz konu alanıyla ilgili bilişsel yapılarının büyük oranda kavramlar arasında tek yönlü ilişkilendirmeleri içeren, çift yönlü ve çapraz ilişkilendirmelerin olmadı̆̆ı statik bir yapı arz ettiği gözlendi. Ayrıca kimya öğretmeni adaylarının asit-baz konu alanıyla ilgili bilişsel yapılarında yer alan kavramlar arasındaki ilişkilerin yapısal karakteristiklerinin tanttıcı/nedensel bilgi düzeyinde yoğunlaştığı gözlendi. Elde edilen bulgular ilgili çalışmalarla karşılaştırılarak tartışıldı ve bulgulara dayalı olarak asit baz konu alanının öğretimine yönelik kimya öğretmeni eğitimcilerine yönelik spesifik önerilerde bulunuldu.

Anahtar Kelimeler: Asit, Baz, Bilişsel Yapı, Kelime İlişkilendirme Testi, Serbest-Yazma Tekniğ i 


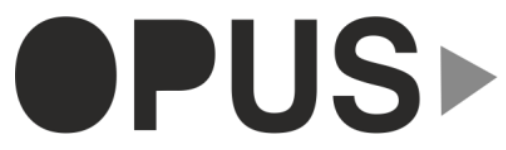

Uluslararası Toplum Araştırmaları Dergisi International Journal of Society Researches
E-ISSN : 2528-9535

YIl Year: 10

Cilt Volume: 16

Sayı Issue :Eğitim ve Toplum Özel Sayısı

Aralık December 2020

Makalenin Geliş Tarihi Received Date: 28/09/2020

Makalenin Kabul Tarihi Accepted Date: 29/12/2020

\title{
Prospective Chemistry Teachers'Cognitive Structure Related To Asit-Base Domain
}

\begin{abstract}
The aim of this research is to determine descriptive and structural features of the cognitive structures of the prospective chemistry teachers related to the acid-base domain. For this purpose, the study group of the research consists of twenty nine prospective chemistry teachers studying chemistry at the university studying in the 2018-2019 academic year. University students participating in the study are students who continue their undergraduate and graduate education in the Department of Chemistry Teaching at a public university in a city center in the Central Anatolia Region. The research is a cross-sectional study. According to the results obtained from the research, it has been observed that the cognitive structures of the chemistry teacher candidates related to the acid-base subject have a static structure that does not include bidirectional and cross-correlation and one-way associations between concepts. In addition, it was determined that the concept maps created by the students could not make associations between the concepts that should be related to each other, and the limited or erroneous concepts developed by students in the context of basic topics create obstacles in the meaning of the concepts related to advanced topics.
\end{abstract}

Keywords: Acid, Base, Cognitive Structure, Word Association Test, Free-Writing Technique 


\section{Giriş}

Kimya eğitiminin esas amaçlarından biri öğrencilerin kimya biliminin önemini kavramalarını, kimya ile ilgili kavramlar hakkında bilgi sahibi olmalarını ve bu kavramları günlük hayattaki problemlerin çözümünde kullanmalarını desteklemektir (MEB, 2018). Bununla birlikte öğrencilerin kimya problemlerini çözmekte zorlandıkları da bir gerçektir. Öğrenciler için kimya problemlerini çözmedeki en büyük engel kimya kavramlarını anlamamaları olabilir (Uzuntiryaki ve Geban, 2005). Kimya öğrenimi için entelektüel düşünme ve kavrayış (Blake ve Norland, 1978) gibi bazı gerekliliklere ihtiyaç vardır. Bu yüzden öğrencilerin kimya kavramları ile ilgili mantıksal düşünme becerisine sahip olmaları gerekir, çünkü kimya içeriği çözünme (Abraham, Williamson ve Westbrook, 1994; Adadan, 2014; Adadan ve Savaşçı, 2012; Çalık, 2005; Çalık, Ayas ve Coll, 2007; Ebenezer ve Gaskel 1995; Stavridou ve Solomonidou, 1989), maddenin tanecikli yapısı (Adadan, Trundle ve Irving, 2010; Liu ve Lesniak, 2005; 2005a), kimyasal bağlar (Othman, Treagust ve Chandrasegaran, 2008) gibi çok sayıda soyut ve teorik kavramlarla doludur. Kimyasal olaylara ilişkin süreçleri (erime, buharlaşma, çözünme, difüzyon, elektron transferi, iyon iletimi, moleküller arası bağ, kimyasal tepkimeler gibi) kavramak lise kimyasını öğrenmek için temel teşkil eder ve kritik öneme sahiptir (Ebenezer, 2001). Canpolat, Pınarbaşı, Bayrakçeken ve Geban (2004) nitelikli bir kimya öğretimi için öğrencilerin kavrama niteliklerinin ve yanlış kavramalarının belirlenmesinin önemine (program geliştiricilere ve öğrencilerin kavramsal düzeyde öğrenmelerini sağlamak amacı ile onlara rehberlik eden öğretmenlere yardımcı olması açısından) vurgu yaparak kimyanın bazı temel konularında (maddenin tanecikli yapısı, asit-baz ve elektrokimya) geçen kavramlarla ilgili öğrencilerin sahip olduğu yanlış kavramaların belirlenmesi amacıyla bir çalışma yürütmüşlerdir. Çalışmalarının sonucunda öğrencilerin ele alınan konularda kavramsal öğrenmede genel olarak güçlük çektiklerini tespit etmişlerdir. Öğrencilerin anlamlı ve kalıcı bilgiye ulaşmalarının, kavramları ve kavramlar arası ilişkileri iyi öğrenmeleri ile mümkün olacağını belirtmişlerdir. Bu bağlamda öğrencilerin kimya konularını kavramsal olarak ne kadar anladıklarını ve konuların kavramsal değişimi sağlamada ne kadar başarılı olduklarını belirlemek önem taşımaktadır (Ercan, Taşdere ve Ercan, 2010). Bir öğrenme-öğretme ortamının etkinliği ve verimi, büyük ölçüde, öğrencilerin kavramsal öğrenmelerine sağladığı katkı ile ilişkilidir. 
Buna göre, verilen eğitimin niteliğinin belirlenebilmesi için, öğrencilerde kavram yoklaması yapılarak öğretimin buna yönelik olarak planlanması gerekmektedir (Canpolat vd., 2004). Bu bulgular bilişsel öğrenme teorilerinin önerdiği yaklaşımları desteklemektedir. Buna göre "Öğrenciler sınıfa kendi deneyimleriyle ve bu deneyimlerden oluşmuş bilişsel yapılarıla gelirler. Daha önce oluşturulan bu yapılar geçerli, geçersiz ya da eksik olabilir. Öğrenci, ancak yeni bilgi ve deneyimleri öncekilerle bir ilişki kurmak suretiyle bilişsel yapısın yeniden düzenler" (Arslan, 2007: 46). Bu bağlamda geleceğin kimya öğretmenleri olan kimya öğretmeni adaylarının kimyanın temel konu alanlarından biri olan asit-bazlarla ilgili bilişsel yapılarının betimsel ve yapısal özelliklerinin bütüncül olarak belirlenmesi önemli bulundu ve bu araştırmada, kimya öğretmeni adaylarının asit-baz konu alanıyla ilgili bilişsel yapılarının belirlenmesine odaklanıldı.

\section{Araştırmanın Amacı}

Bu araştırmanın amacı kimya öğretmeni adaylarının asit-baz konu alanıyla ilgili bilişsel yapılarında hangi kavramların yer aldığını, kavramlar arası ilişkilerin yönünü, gücünü ve yapısını belirlemek, bir başka ifadeyle, öğrencilerin asit-baz konu alanıyla ilgili bilişsel yapılarının betimsel ve yapısal özelliklerini belirlemektir. Bu genel amaç kapsamında "Kimya öğretmeni adaylar1nın asit-baz konu alanıyla ilgili bilişsel yapılarının betimsel ve yapısal özellikleri nasıldır?" sorusuna cevap arandı.

\section{Araştırmanın Önemi}

Yukarıda detaylı bir biçimde sunulan asit-baz konusuyla ilgili çalışmaların ortaya koyduğu bilgiler ışığında, öncül çalışmalarda daha çok kullanılan öğretim yöntem ve yaklaşımın veya materyalin öğrenci başarısına etkisine odaklanıldığını ve çoğunlukla nicel araştırma bakış açısıyla yürütüldüğünü görmekteyiz. Bu çalışma ise öğrencilerin asit baz konusu ile ilgili bilişsel yapılarını betimsel ve yapısal özellikleri bakımından bütüncül ve detaylı bir biçimde ele alması yönüyle özgündür.

Ayrıca öğrencilerin kimyanın temel konulanlarından olan asitler-bazlarla ilgili bilişsel yapıların bütüncül bir biçimde belirlenmesinin, program geliştiricilere, kitap yazanlara, kimya öğretmenlerine, kimya eğitimi araştırmacılarına katkı sağlayacak olması bakımından önemli olduğu ve alana katkı sağlayacağı düşünülmektedir. 


\section{Yöntem}

Bu araştırmada yöntem olarak durum çalışması kullanılmıştır. Bu yöntemin kullanılmasının nedeni çalışmada kimya öğretmeni adaylarının asit-baz konu alanıyla ilgili bilişsel yapılarının betimsel ve yapısal olarak detaylı bir biçimde ele alınması, ortaya çıkan yapılar içerisinde nedensel bağlantı olduğu varsayılan olayların açıklanmasıdır (Subaşı ve Okumuş, 2017). Bu çalışmada kimya öğretmeni adaylarının asit-baz konu alanıla ilgili bilişsel yapıları incelenen durum olarak düşünüldü.

\section{Örneklem}

Bu araştırma 2018-2019 akademik yılında öğrenimlerine devam eden kimya öğretmeni adayları ile yürütüldü. Çalışmaya katılan toplam 29 kimya öğretmeni adayı İç Anadolu Bölgesi'nde yer alan bir il merkezinde bulunan devlet üniversitesinde lisans ve yüksek lisans öğrenimlerine devam etmektedir. Bunlardan 13 tanesi lisans 3. sinif, 10 tanesi lisans 4. sinff ve kalan 6 tanesi ise yüksek lisans öğrencisidir. Öğrenciler kimya öğretmenliği programına birbirine yakın veya benzer puanlarla kayıt yaptırmıştır. Katılımcıların demografik özellikleri ile ilgili bilgiler aşağıda Tablo 1 de sunuldu.

Tablo 1. Kimya öğretmeni adaylarnın demografik özellikleri

\begin{tabular}{lll}
\hline Demografik Özellik & $\boldsymbol{F}$ & $\mathbf{\%}$ \\
\hline Cinsiyet & & \\
Kız & 23 & 79,31 \\
Erkek & 6 & 20,69 \\
Toplam & $\mathbf{2 9}$ & $\mathbf{1 0 0}$ \\
\hline Yass & & \\
19 & 1 & 3,45 \\
20 & 8 & 27,6 \\
21 & 9 & 31 \\
22 & 4 & 13,8 \\
23 & 1 & 3,45 \\
25 & 2 & 6,9 \\
26 & 2 & 6,9 \\
27 & 1 & 3,45 \\
34 & 1 & 3,45 \\
Toplam & $\mathbf{2 9}$ & $\mathbf{1 0 0}$ \\
Ortalama & $\mathbf{2 2 , 1 4}$ & \\
\hline
\end{tabular}


Tablo 1'e göre 29 katılımcının 23'ü (\%79,31) kız; 6's1 (20,69) erkektir. Katılımcıların yaşlarının minimum değeri 19 maksimum değeri 34 olmakla birlikte yaş ortalamaları 22,14'dür.

\section{Veri Toplama Araçları}

Bu araştırmada veri toplama aracı olarak Kelime İlişkilendirme Testi ve Serbest Yazma Tekniği kullanıldı. Aşağıda veri toplama araçları ile ilgili bilgiler sunulmaktadır.

Kelime İlişkilendirme Testi (KITT): KİT, “Anahtar kavrama (uyarıcı kelime) verilen cevap kelimelerine bağh olarak kişilerin bilişsel yapısındaki kavram ve kavramlar arası bağları araştırmak için kullanılan en eski ve en yaygin araçlardan iridir" (Doğan, Yücel Güngör ve Güngör, 2017). Öğrenciler kendilerine verilen süre içerisinde verilen kavramla ilgili zihinlerinde oluşan bütün kavramları cevap olarak verebilirler. Buradan öğrencilerin verdikleri cevaplara ve cevapların sayısına bakılarak konuyu tam olarak anlayıp anlamadıkları belirlenebilir. "Bu yöntemle öğrencilerin zihninde, uyarncı kavramla ilişkilendirilmiş olan kavramlarm listesi elde edilir. Yöntem, bireyin hangi kavramlar arasında ilişki kurduğunu göstermekle birlikte ilişkinin doğası hakkında bilgi vermez" (Köseoğlu ve Bayır, 2011). Tekniğin hazırlanması, uygulanma aşaması kolay ve hızlıdır. Tek kişiye uygulanabildiği gibi gruba da uygulanabilir. Fakat teknikte değerlendirme işlemi uzun sürmektedir (Derman ve Eilks, 2016; Nakipoğlu, 2008).

$\mathrm{Bu}$ araştırmada öğrencilerin asit-baz konu alanıyla ilgili bilişsel yapılarında yer alan kavramlar ve kavramlar arası ilişkilerin yönü ve gücü hakkında bilgi sahibi olmak için KİT kullanıldı. KİT oluşturma sürecinde uzman (analitik kimya alanında bir profesör) görüşü doğrultusunda "Asit, baz, asitlik, bazlık, tuz, nötralleşme, indikatör, $\mathrm{pH}$, tampon çözelti, amfoter tür, konjuge asit-baz çifti" kavramları asit baz konu alanıyla ilgili uyarıcı kavramlar/kelimeler olarak belirlendi. Uyarıc kelimelerin her biri ayrı bir sayfaya ve alt alta 10 kez yazmak kaydıyla (yazılan cevap kelimenin yaratacağı zincirleme etkiyi yok etmek için) (bkz. Şekil 1) bir kitapçık oluşturuldu. KIT' in veri toplama aracı olarak kullanıldığı çalışmalarda her bir uyarıcı kelimenin cevaplanması için 30 saniye (Nakipoğlu, 2008) veya 1 dakika (Gunstone, 1980; Shavelsen, 1972) zaman verildiği görülmektedir. Bu çalışmada kimya öğretmeni adaylarına KİT kitapçığını tamamlamaları için toplam 15 dakika süre 
verilmiştir. Bu çalışmada kullanılan kelime ilişkilendirme testine ait form aşağıdaki şekilde hazırlanmıştır (Şekil 1).

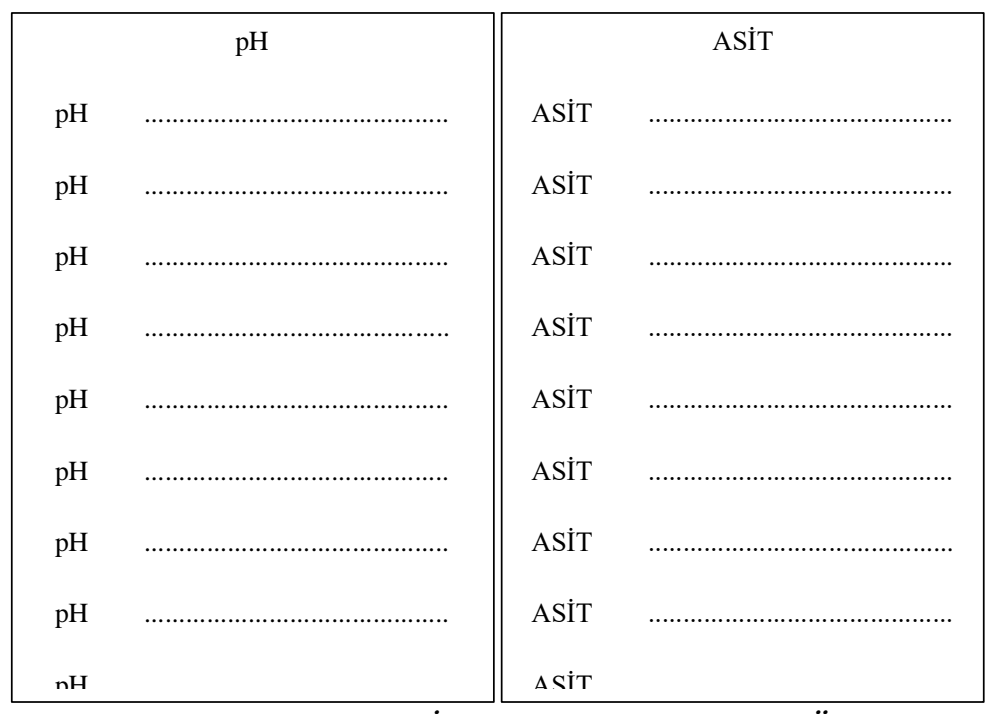

Şekil 1. Hazırlanan Kelime İlişkilendirme Testinden Bir Örnek

Şekil 2'de katılımcılardan bağımsız kelime ilişkilendirme testiyle toplanan verilere ait örneklere yer verilmiştir (K 20).
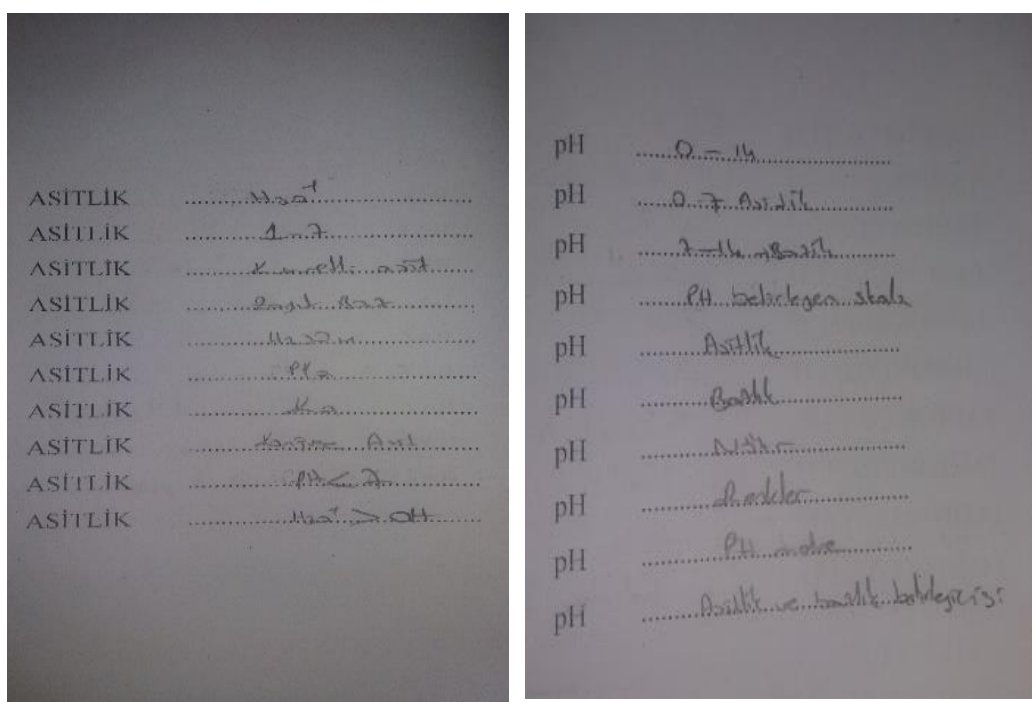

Şekil 2. Kelime İişkilendirme Testi Uygulama Örnekleri 
Serbest Yazma Tekniği (SYT): KİT öğrencilerin bilişsel yapılarındaki kavramları ve bu kavramların sıklıklarını, gücünü ve yönünü belirlemede oldukça etkin olmasına rağmen; kavramlar arası ilişkilerin doğasını (bilişsel yapılarının yapısal unsurlarını) belirleme bakımından bazı sınırlılıklar barındırmaktadır (Nakipoğlu, 2008). Bu çalışmada KİT'in yapısından kaynaklanan bu s1nırlığın üstesinden gelerek öğrencilerin asit-baz konu alanıyla ilgili bilişsel yapılarının betimsel ve yapısal özelliklerini detaylı ve bütüncül bir biçimde belirleyebilmek için, ilgili araştırmalardaki (Derman ve Ebenezer, 2018; Derman ve Eilks, 2016; Nakipoğlu, 2008) öneriler dikkate alınarak, KİT ve SYT birlikte kullanıldı. Ayrıca bu durum veri toplama tekniği açısından çeşitleme (triangulation) sağladığı için çalışmanın güvenirliğini artıran bir mekanizma olarak da görülebilir. SYT düşüncelerin belli bir plan dâhilinde yazıya dökülmesidir (Calp, 2013). "Öğrencinin uzun süreli belleğinden verdiği bu cevaplarm, bilişsel yapısındaki kavramlar arası bağları belirlediği ve anlamsal yakınlı̆̆ gösterdiğ $i$ farz edilmektedir" (Bahar ve Özatll, 2003; akt. Tavukçuoğlu, 2018). Bu çalışmada KİT'in son sayfasında öğrencilerden KİT'te yer alan uyarıcı kelimeler olan "Asit, baz, asitlik, bazlık, tuz, nötralleşme, indikatör, $\mathrm{pH}$, tampon çözelti, amfoter tür, konjuge asit-baz çifti" kavramlarını kullanarak ve bu kavramların birbiriyle ilişkisini ele alan, belirleyen genişçe bir paragraf yazmaları istendi. Bunun için öğrencilere 30 dakika süre verildi. Öğrencilerin kendi el yazılarıyla kaleme aldığı paragraflar araştırmanın bu kısmına ait veri kaynağını oluşturdu (Şekil 3).

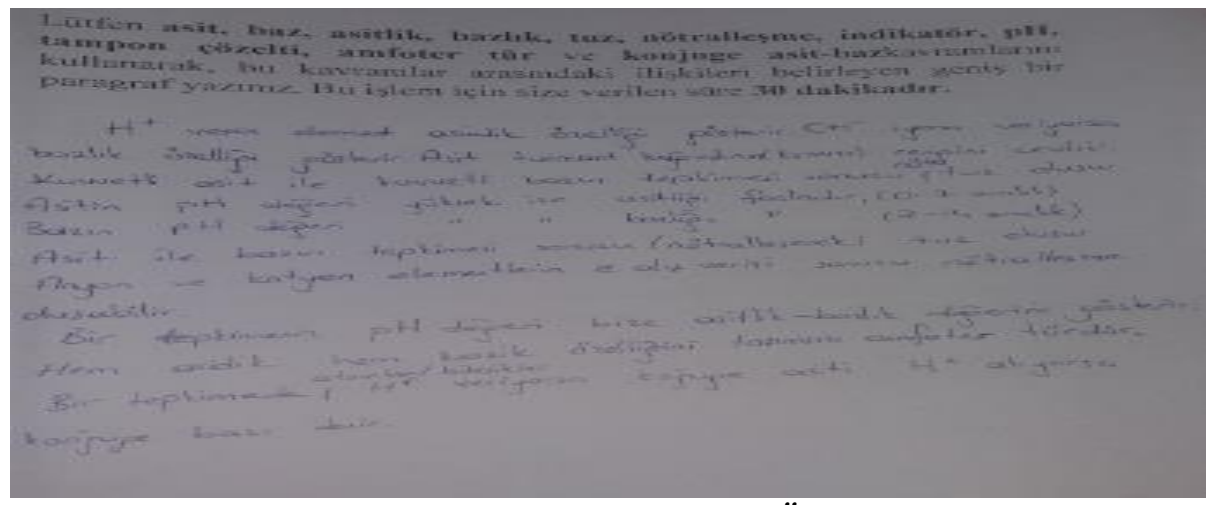

Şekil 3. Paragraf Yazma Uygulama Örneği (K 15) 


\section{Veri Analizi}

Üniversite öğrencilerinin cevap kağıtları 1'den 29'a kadar numaralandırıldı. KİT ile toplanan verilerin analizinde öğrencilerin "asit, baz, asitlik, bazlık, tuz, nötralleşme, indikatör, $\mathrm{pH}$, tampon çözelti, amfoter tür, konjuge asit-baz çifti" kavramlarıyla ilgili bilişsel yapılarının organizasyonunu belirlemek için söz konusu uyarıcı kelimelere karşılık öğrencilerin yazdıkları cevap kelimelere dayalı olarak "cevap kelime frekanslarına bağlı haritalama tekniği" (Derman ve Ebenezer, 2018; Derman ve Eilks, 2016; Nakipoğlu, 2008) kullanıldı. Bu yöntemde, cevap kelime sayısı ve anlamsal ilişki kriterleri esas alınarak, ilk önce uyarıcı ve cevap kelimelerini içeren bir frekans tablosu oluşturulur ardından bu tablodaki frekans değerlerine göre bilişsel harita oluşturulur. Bilişsel haritaların nasıl oluşturulduğunu açıklamak için frekans tablosunda (bkz. Tablo 6) yeterli olduğu düşünülen (Bu çalışma çok fazla sayıda cevap kelime içerdiğinden) örnek frekans değerleri sunuldu. Tablo $6^{t}$ da uyarıcı kelimelere ilk satırda; cevap kelimelere ilk sütunda yer verildi. Frekans tablosu, okların yönünü ve haritadaki ilişkilerin gücünü belirler. Haritadaki okların yönü, kalınlığı frekans değerlerine göre belirlendi. Haritada kavramlar arası ilişkinin yönü okların yönüyle (ilişkilendirmeler tek yönlü olduğunda tek yönlü okla, çift yönlü olduğunda çift yönlü okla gösterildi) ve ilişkinin gücü okların kalınlığı ile temsil edildi. Bu çalışmada haritayı oluşturmaya başlamadan önce içerik analizi yapıldı. İçerik analizi 1. Eleme-ayıklama 2. Kodlama olmak üzere başlıca iki aşamada gerçekleştirildi. Eleme-ayıklama aşamasında önce öğrencilerin yazdıkları cevap kelimelerden asit ve baz konu alanı bağlamında geçerli ve anlamlı olanlar bilgisayar ortamına aktarıldı. Daha sonra asit-baz konu alanı bağlamında anlamsız ve geçersiz olduğu düşünülen cevap kelimeler (sıfırlaşma, nötürleşme atomlaşmadır, su göstergesi gibi) elendi. Kodlama aşamasında ise benzer özellik gösteren bazı kelimeler/kavramlar aynı kod altında toplanarak (Tablo 2) analizler gerçekleştirildi. Bu aşamada kodlamalar yapılırken kavramların benzer özellikleri baz alındı. Örneğin alkol, bira, soda, gazoz, kola, maden suyu, asitli içecekler, enerji içeceği gibi kavramlar benzer özellik olarak içerisinde gaz barındırması nedeniyle gazlı içecekler olarak kodlandı. Şampuan, diş macunu, duş jeli, krem, el kremi gibi kavramlar kişisel temizlikte kullanıldığı için kişisel temizlik maddeleri olarak kodlandı. Çamaşır suyu, aspirin, cif, bulaşık deterjanı, tuz ruhu, deterjan, lavabo açıcı gibi kavramlar ev temizliğinde kullanıldığı 
için ev temizlik maddeleri olarak kodlandı. Ananas, armut, çilek, elma, erik, mandalina, portakal, muz, nar, domates, alıç, karpuz, kavun, şeftali, üzüm gibi kavramların benzer özelliklerinin meyve olmasından dolayı meyve olarak, aynı şekilde soğan, biber gibi kavramlar ise sebze olarak kodlandı. Zn, $\mathrm{Cr}, \mathrm{Al}, \mathrm{Pb}, \mathrm{Sn}, \mathrm{B}$ elementleri amfoter metal elementleri olduğundan amfoter metal olarak kodlandı. Diğer kodlamalar da yukarıda verdiğimiz örnekler gibi kavramların benzer özelliklerine göre oluşturuldu.

Tablo 2. KIT ile elde edilen verilerden benzer özellik gösteren kavramlar ve dâhil edildikleri kodlar

\begin{tabular}{|c|c|}
\hline Kavramlar & Kodlar \\
\hline Alkol, bira, soda, gazoz, kola, maden suyu, asitli içecekler, enerji içeceği & Gazlı İçecekler \\
\hline Limon suyu & Limon \\
\hline Limonun pHölçümü & pHÖlçümü \\
\hline Çamaşır sabunu & Sabun \\
\hline $\begin{array}{l}\text { Ananas, armut, çilek, elma, erik, mandalina, portakal, muz, nar, domates, } \\
\text { alıç, karpuz, kavun, şeftali, üzüm }\end{array}$ & Meyve \\
\hline $\mathrm{HCI}+\mathrm{NaOH}$ & Asit Baz Tepkimesi \\
\hline $1,2,3,4,5,6,7,8,9,10,11,12,13,14$ & Değer \\
\hline Şampuan, diş macunu, duş jeli, krem, el kremi, & Kişisel Temizlik Maddeleri \\
\hline Çamaşır suyu, aspirin, cif, bulaşık deterjanı, tuz ruhu, deterjan, lavabo açıcı & Ev Temizlik Maddeleri \\
\hline $\mathrm{CH}_{3} \mathrm{COOH} / \mathrm{CH}_{3} \mathrm{COO}^{-}$ve $\mathrm{NH}_{4} / \mathrm{NH}_{3}$ & Zaylf Asit ve Tuzu \\
\hline Soğan, biber & Sebze \\
\hline Temizlik maddeleri & $\begin{array}{l}\text { Kişisel Temizlik Maddeleri + Ev Te- } \\
\text { mizlik Maddeleri }\end{array}$ \\
\hline $\mathrm{Zn}, \mathrm{Cr}, \mathrm{Al}, \mathrm{Pb}, \mathrm{Sn}$, B elementleri & Amfoter Metal \\
\hline HCOOH, Karınca Asidi & Formik Asit \\
\hline
\end{tabular}

Veriler yukarıda belirtilen esaslara göre ayıklanıp, kodlandıktan sonra öğrencilerin her bir uyarıcı kelimeye karşılık yazdıkları cevap kelimeler sayılarak frekans tablosu (Tablo 6) oluşturuldu.

Veri analiz süreciyle ilgili olarak güvenirliği sağlamak için on öğrenciye ait KİT verileri bu tezin de danışmanı olan kimya eğitimi uzmanına aktarıldı, on öğrenciye ait veriler uzman ve araştırmacı tarafından bağımsız bir biçimde kodlanarak, Miles ve Huberman'ın Güvenirlik Formülüne [Güvenirlik=(Görüş Birliği / Görüş Birliği + Görüş Ayrılığı) × 100] göre güvenirlik hesaplamaları yapıldı. Nitel analize dayalı çalışmalarda \%70 ve üzeri ideal güvenirlik aralığ 1 olarak değerlendirilmektedir (Miles ve Huberman, 1994). Bu çalışmada kodlayıcılar arası güvenirlik hesaplamasında her bir uyarıcı kelime için iki bağımsız kodlamaya ait farklı cevap kelime sayısına odaklanıldı. İlk kodlamada güvenirlik değeri \%70'in altında olan uyarıcı kelimelere (Bazlık=\%65, 
Nötralleşme $=\% 62$, Tampon çözelti $=\% 50$, Konjuge asit-baz çifti=\%50) ait kodlamalar üzerinde uzman ve araştırmacı tartışarak kodlamalara dair fikir birliği sağlandıktan sonra bu uyarıcı kelimelerle ilgili kodlamalar tekrar yapıldı ve böylece güvenirlik hesaplamaları tekrarlanarak tamamlandı (Tablo 3). Analize ait güvenirlik Tablo 3'te sunulduğu şekliyle standardize edildikten sonra araştırmacı kodlamaları bireysel olarak tamamladı.

Tablo 3. Asit-Baz konusuyla ilgili anahtar kavramlarn güvenirlik hesaplarn

\begin{tabular}{|c|c|c|c|}
\hline Kavramlar & & Güvenirlik Hesaplamaları & Yüzde \\
\hline Asit & Güvenirlik=(18/18+5)×100 & $\%$ 78 & \\
\hline Baz & Güvenirlik $=(18 / 18+5) \times 100$ & $\% 78$ & \\
\hline Asitlik & Güvenirlik=(24/24+4)×100 & $\% 86$ & \\
\hline Bazlık & Güvenirlik=(18/18+2)×100 & $\% 90$ & \\
\hline Tuz & Güvenirlik=(10/10+3)×100 & $\% 77$ & \\
\hline Nötralleşme & Güvenirlik=(10/10+1)×100 & $\% 91$ & \\
\hline İndikatör & Güvenirlik $=(4 / 4+0) \times 100$ & $\% 100$ & \\
\hline $\mathrm{pH}$ & Güvenirlik= $(5 / 5+2) \times 100$ & $\% 71$ & \\
\hline Tampon Çözelti & Güvenirlik $=(2 / 2+0) \times 100$ & $\% 100$ & \\
\hline Amfoter Tür & Güvenirlik $=(5 / 5+0) \times 100$ & $\% 100$ & \\
\hline Konjuge Asit Baz & Güvenirlik= $(3 / 3+1) \times 100$ & $\% 75$ & \\
\hline
\end{tabular}

SYT ile elde edilen verilerin analizinde ise Liu ve Ebenezer' in (2002) Holley ve Dansereau'dan (1984) adapte ederek geliştirdikleri "yapısal karakteristikleri tanımlamak için ilişki tipleri" çerçevesinden (Tablo 5) yararlanıldı.

SYT ile elde edilen paragraflarm analizinde öncelikle paragraflarm tamamı bilgisayar ortamına aktarıldı ve bunlardan on tanesi uzman ve araştırmacı tarafından bağımsız olarak Tablo 5'te sunulan çerçeveye göre analiz edildi. Paragraflar analiz edilirken kodlayıcılar her bir ilişki türünü kodlamak için her bir ilişki türü için önceden belirledikleri farklı renkleri kullandı (kodlayıcılar aynı ilişki türünü kodlamak için aynı rengi kullandı. Mesela parçası/bölümü ilişkisini kodlamak için her iki kodlayıcı da kırmızı rengi kullandı, Örnek/çeşit ilişkisini kodlamak için mavi renk kullanıldı gibi). Paragraf analizleriyle ilgili güvenirlik temin edildikten sonra analizler araştırmacı tarafından bireysel olarak tamamlandı. Güvenirlik hesaplamalarında yine Miles ve Huberman'ın Güvenirlik Formülü kullanıldı. Her bir ilişki türü için kodlayıcılar arası güvenirlik hesaplamasında \%70'in üzerinde bir değere ulaşıldığı gözlendi. Uzman ve araştırmacı tarafından yapılan paragraf analizlerinin güvenirlik hesaplamaları aşağıda Tablo 4'te verilmiştir. 
Tablo 4. Kimya öğretmeni adaylarna ait paragraflar ile ilgili güvenirlik hesaplamalar

\begin{tabular}{lll}
\hline İlişki Türü & Güvenirlik Hesaplamaları & Yüzde \\
\hline Parçası/bölümü ilişkisi & Güvenirlik $=(12 / 12+2) \times 100$ & $\% 85,7$ \\
\hline Örnek/çeşit ilişkisi & Güvenirlik $=(18 / 18+1) \times 100$ & $\% 94,7$ \\
\hline Neden/öncüllük ilişsisi & Güvenirlik $=(26 / 26+0) \times 100$ & $\% 100$ \\
\hline Analoji İlişkisi & Güvenirlik $=(2 / 2+0) \times 100$ & $\% 100$ \\
\hline Karekteristik İlişki & Güvenirlik $=(31 / 31+4) \times 100$ & $\% 88,6$ \\
\hline Kanit İlişkisi & Güvenirlik $=(12 / 12+0) \times 100$ & $\% 100$ \\
\hline
\end{tabular}

Tablo 5. Bilişsel yapılardaki ilişkilendirmelerin yapısal karakteristiklerini tanımlamak için ilişki tipleri (Akt: Liu ve Ebenezer, 2002)

\begin{tabular}{ll}
\hline İlişki & Açıklama \\
\hline $\begin{array}{l}\text { Parçası/bölümü ilişkisi } \\
\text { (Part- of relationship) }\end{array}$ & $\begin{array}{l}\text { Bir nesnenin kısımlarına, bir şeyin kompozisyonuna, bir fikrin unsurlarına } \\
\text { veya bir şey yapma sürecine atıfta bulunur. }\end{array}$ \\
\hline $\begin{array}{l}\text { Örnek/çeşit ilişkisi } \\
\text { (Type- of/example- of relationship) }\end{array}$ & $\begin{array}{l}\text { Bir sınıfa veya kategoriye ait üyelere veya örneklere; şey veya nesnelerin } \\
\text { farklı gruplarının etiketlerine atıfta bulunur. }\end{array}$ \\
\hline $\begin{array}{l}\text { Neden/Öncüllük ilişkisi } \\
\text { (Lead- to relationship) }\end{array}$ & Nedensel bir etki, bir değişiklik veya sıralı bir işleme atıfta bulunur. \\
\hline $\begin{array}{l}\text { Analoji ilişkisi } \\
\text { (Analogy relationship) }\end{array}$ & Mantıksal karşlaştırmalara atıfta bulunur \\
\hline $\begin{array}{l}\text { Karakteristik ilişki } \\
\text { (Characteristics realtionship) }\end{array}$ & Özelliklere, farklı yönlere, detaylara, niteliklere veya bir nesnenin, işlem, \\
\hline Kanıt ilişkisi & Delillere, verilere, desteklere, kanıtlara, belgelere, önlemlere veya bir nesne, \\
(Evidence relationship) & fikir, süreç veya kavramın doğrulanmasına, onayına atıfta bulunur. \\
\hline
\end{tabular}

\section{Bulgular}

Bu bölümde sırasıyla KİT ve SYT ile elde edilen verilerin analiziyle ulaşılan bulgulara yer verilmiştir.

\section{KİTe İlişkin Bulgular}

Bu bölümde öğrencilerin uyarıcı kelimelere verdikleri cevap kelimeler analiz edilerek KİT'e ait frekans değerleri tablosu oluşturuldu. Tablonun küçük bir kısmı örnek teşkil etmesi amacıyla aşağıda verildi (Tablo 6). 
Tablo 6. Kimya öğretmeni adaylarnna ait kit frekans değerleri tablosu örneği

\begin{tabular}{|c|c|c|c|c|c|c|c|c|c|c|c|c|}
\hline Cevap Kelimeleri & Uya & $1 \mathrm{Kel}$ & eler & & & & & & & & & $\begin{array}{l}\text { Toplam } \\
\text { Cevap Kelime }\end{array}$ \\
\hline & 䓪 & ల్ & 总 & 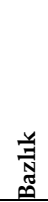 & $\stackrel{ }{\Xi}$ & 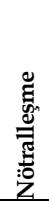 & 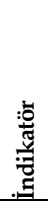 & $\frac{\pi}{2}$ & 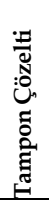 & 泀 & 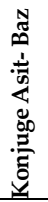 & \\
\hline Asit & - & 2 & - & - & 8 & 7 & 7 & 10 & 6 & 7 & 5 & 52 \\
\hline $\mathrm{Asit}+\mathrm{Baz} \rightarrow \mathrm{Tuz}+\mathrm{Su}$ & 8 & 14 & 1 & 2 & 9 & 7 & 1 & 2 & - & - & 2 & 46 \\
\hline Baz & 3 & - & - & - & 8 & 7 & 7 & 10 & 5 & 6 & 5 & 51 \\
\hline $\mathrm{H}^{+}$ & 16 & - & 6 & - & - & - & - & 1 & - & - & 1 & 24 \\
\hline $\mathrm{H}_{3} \mathrm{O}^{+}$ & 7 & - & 4 & - & - & - & - & 1 & - & - & 1 & 13 \\
\hline Konjuge asit & 15 & 1 & 3 & - & - & - & - & - & 3 & - & - & 22 \\
\hline Konjuge baz & 1 & 13 & 1 & 2 & - & - & - & 1 & 3 & - & - & 21 \\
\hline Kuvvetli asit & - & - & 8 & 1 & - & & 1 & & 1 & - & 4 & 15 \\
\hline $\begin{array}{l}\text { Kuvvetli asit ve zayıf } \\
\text { Baz tepkimesi }\end{array}$ & - & - & - & - & 1 & - & - & - & 2 & - & 5 & 8 \\
\hline Kuvvetli baz & - & - & - & 5 & - & - & 1 & - & 1 & - & 3 & 10 \\
\hline Nötr & 1 & - & 1 & - & 8 & 4 & 1 & 4 & - & 1 & & 20 \\
\hline $\mathrm{OH}^{-}$ & - & 20 & - & 5 & - & - & - & - & - & - & 1 & 26 \\
\hline $\mathrm{pH}$ & 6 & 3 & 5 & 3 & - & - & 6 & - & 5 & - & 3 & 31 \\
\hline $\mathrm{Su}$ & - & 2 & - & 3 & 4 & 5 & - & - & - & 7 & - & 21 \\
\hline Tampon çözelti & - & 1 & - & - & 1 & & 1 & - & - & - & 8 & 11 \\
\hline Tepkime & 3 & 4 & 4 & 3 & - & 9 & 4 & 1 & 2 & 2 & 1 & 33 \\
\hline Titrasyon & & 1 & & & - & - & 12 & 1 & 1 & - & - & 15 \\
\hline Turnusol kâğıdı & 11 & 8 & 2 & 2 & - & - & 5 & 9 & - & - & - & 37 \\
\hline Tuz & 4 & 4 & 1 & 3 & - & 6 & - & 3 & 2 & - & 2 & 25 \\
\hline Zayıf asit & 10 & & 3 & 1 & - & - & - & - & 5 & - & 4 & 23 \\
\hline Zayıf baz & - & 9 & 1 & 3 & - & - & - & - & 5 & - & 4 & 20 \\
\hline
\end{tabular}

KİT ile elde edilen verilere dayalı olarak kimya öğretmeni adaylarının bilişsel yapı haritaları oluşturulurken, öğrencilerin cevap kelimelerine ait frekans değerleri esas alındı. Öğrencilerin asit-baz konu alanıyla ilgili bilişsel yapılarındaki başat kavramları yansıtmak bakımından $11 \leq f \leq 20$ frekans aralığ1nın kullanılması uygun görüldü. Öğrencilerin cevap kelimelerinden frekans değeri $1 \leq f \leq 10$ frekans aralığına tekabül eden kavramlara (Tablo 6) bilişsel yapı haritasında (Şekil 4) yer verilmedi. 


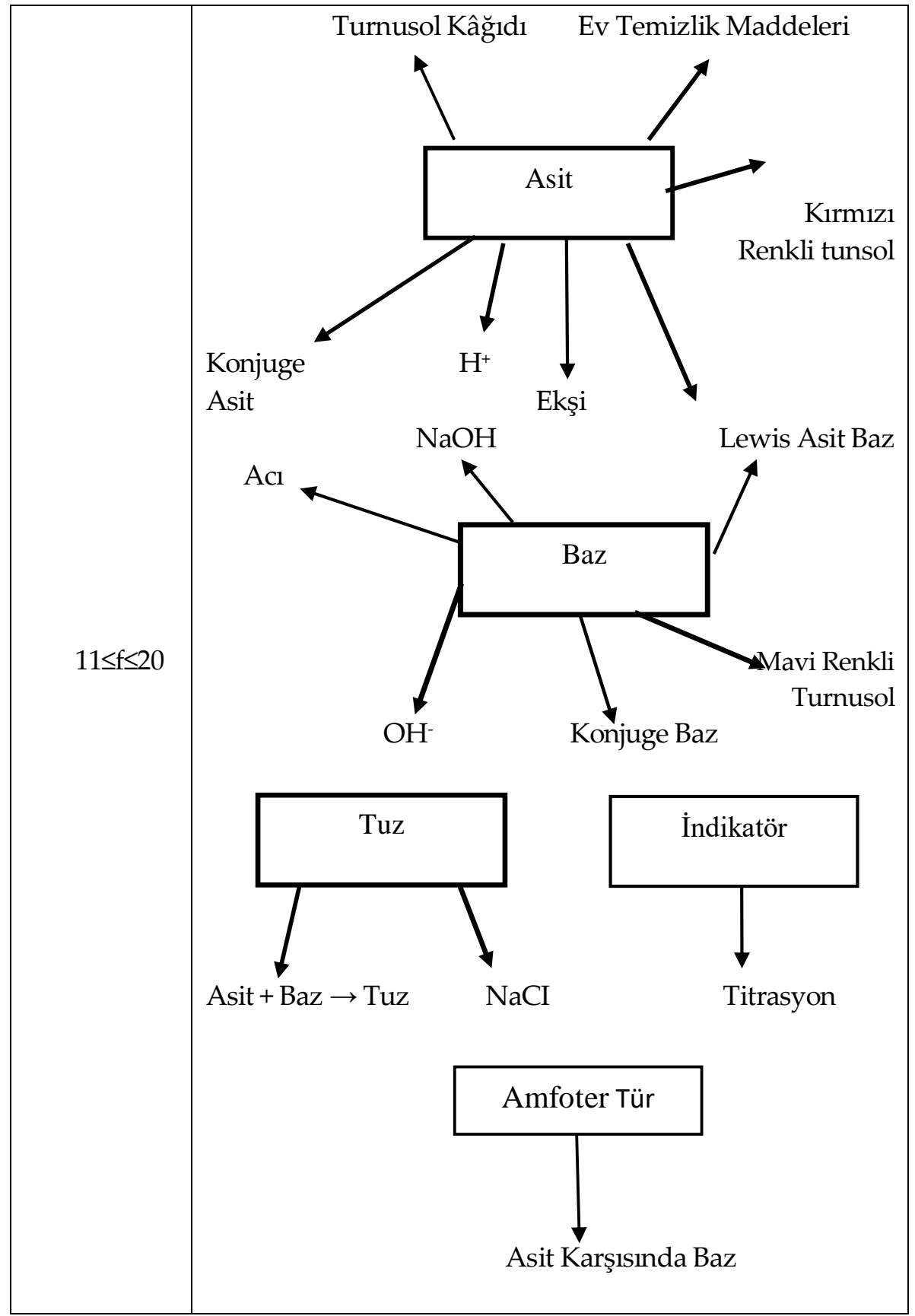

Şekil 4. Kimya öğretmeni adaylarının asit-baz konu alanı ile ilgili başat ilişkilendirmeler içeren bilişsel yapı haritaları 
Şekil 4'te görüldüğü gibi kimya öğretmeni adaylarının asit-baz konu alanıyla ilgili bilişsel yapılarında $11 \leq \mathrm{f} \leq 20$ frekans aralığında beş uyarıcı kelime ayrı hücreler olarak belirdi. "Asit" uyarıcı kelimesinin "turnusol kağıdl, ev temizlik maddeleri, konjuge asit, kırmizı renkli turnusol, ekşi, Lewis asit baz ve $H^{+\prime}$ cevap kelimeleriyle, "baz" uyarıc kelimesinin "Lewis asit baz, $\mathrm{NaOH}, a c 1, \mathrm{OH}$, konjuge baz ve mavi renkli turnusol" uyarıcı kelimeleriyle, "tuz" uyarıcı kelimesinin "Asit $+\mathrm{Baz} \rightarrow$ Tuz ve NaCI" cevap kelimeleriyle, "indikatör" uyarıcı kelimesinin "titrasyon" cevap kelimesiyle ve "amfoter tür" uyarıc kelimesinin "asit karşısında baz" cevap kelimesiyle ayrı hücreler olarak, tek yönlü ilişkilendirmelerle belirtildiği görülmektedir. Bu düzeyde "asit" uyarıcı kelimesi yedi, "baz" uyarıcı kelimesi altı, "tuz" uyarıc kelimesi iki, "indikatör" ve "amfoter tür" uyarıc kelimelerinin ise tek bir cevap kelimesi ile ilişkilendirildiği görülmektedir. Tüm ilişkilendirmeler tek yönlü olmakla birlikte, aynı cevap kelimenin (Lewis asit baz) farklı uyarıc kelimelerle (asit, baz) ilişkilendirildiği gözlendi. Kimya öğretmen adaylarının asit-baz konu alanıyla ilgili bilişsel yapılarında ilişkilendirmelerin gücünün zayıf olduğu, çift yönlü ve çapraz ilişkilendirmelerin olmadığı, kavramlar arasında tek yönlü ilişkilendirmelerin söz konusu olduğu statik bir yapı gözlendi.

Her bir uyarıcı kelimeye verilen farklı cevap kelimelerin sayılması, KİT ile elde edilen verilerin özetlenmesi açısından önemlidir (Bahar, Johnstone ve Sutcliffe, 1999; Nakipoğlu, 2008; Shavelson, 1974). Bu çalışmada haritalamayla ilgili analizlere ek olarak "asit, baz, asitlik, bazlık, tuz, nötralleşme, indikatör, pH, tampon çözelti, amfoter tür, konjuge asit baz" uyarıcı kelimelerine verilen anlamlı ve geçerli farklı cevap kelimelerin sayısı belirlendi ve Tablo 7'de sunuldu.

Tablo 7. Kimya öğretmen adaylarını uyarıcı kelimelere verdikleri farklı cevap kelimelerin toplam sayısı

\begin{tabular}{ll}
\hline Uyarııı Kelimeler & Farklı Cevap Kelimelerin Toplam Sayısı \\
\hline Asit & 66 \\
\hline Baz & 57 \\
\hline Asitlik & 70 \\
\hline Bazlık & 71 \\
\hline Tuz & 48 \\
\hline Nötralleşme & 36 \\
\hline İndikatör & 48 \\
\hline pH & 55 \\
\hline Tampon Çözelti & 43 \\
\hline Amfoter Tür & 17 \\
\hline Konjuge Asit Baz & 32 \\
\hline
\end{tabular}


Uyarıcı kelimelere verilen farklı cevap kelimelerin sayısının 17 ile 71 arasinda değiştiği (Tablo 7) belirlendi. En fazla cevap kelimesinin “bazlık (71) ve asitlik (70)" uyarıcı kelimeleri için verildiği, en az cevap kelimenin ise "amfoter tür (17), konjuge asit baz (32) ve nötralleşme (36)" uyarıcı kelimeleri için verildiği gözlendi.

\section{SYTne İlişkin Bulgular}

Bu bölümde öğrencilerin yazdığı paragrafların analizinden elde edilen bulgulara yer verildi. Kimya öğretmeni adaylarının yazdıkları paragrafların analiziyle elde edilen bulgular Tablo 8'de sunularak öğrencilerin asit-baz konu alanıyla ilgili bilişsel yapılarının yapısal özellikleri ortaya konuldu.

Tablo 8. Kimya öğretmeni adayların asit-baz konu alanı ile ilgili bilişsel yapılarında bulunan ilişkilendirmelerin yapısal karakteristikleri

\begin{tabular}{|c|c|c|c|}
\hline İlişki & $\begin{array}{c}\text { Tanım/ } \\
\text { Açıklama }\end{array}$ & Örnek & \\
\hline Parçası/bölümü ilişkisi & $\begin{array}{l}\text { Bir nesnenin k- } \\
\text { sımlarına, bir şe- } \\
\text { yin kompozisyo- } \\
\text { nuna, bir fikrin } \\
\text { unsurlarına veya } \\
\text { bir şey yapma sü- } \\
\text { recine atıfta bulu- } \\
\text { nur. }\end{array}$ & $\begin{array}{l}\text { 1-Asitlik denildiği zaman aklımıza } \mathrm{H}_{3} \mathrm{O}^{+} \text {iyonu baz de- } \\
\text { nildiği zaman ise } \mathrm{OH} \text { - iyonu gelmektedir. } \\
\text { 2-Lewis'e göre elektron çifti alan asit, elektron çfti ve- } \\
\text { ren bazdır. } \\
\text { 3-Bir maddeden } \mathrm{H}^{+} \text {kopardığımız zaman yeni madde } \\
\text { baştakinin konjuge asidi olur. Aynı şekilde } \mathrm{OH}^{-} \text {kopar- } \\
\text { dığımız zaman konjuge bazı olur. }\end{array}$ & 44 \\
\hline Örnek/çeşit ilişkisi & $\begin{array}{l}\text { Bir sinıfa veya ka- } \\
\text { tegoriye ait üye- } \\
\text { lere veya örnek- } \\
\text { lere; şey veya nes- } \\
\text { nelerin } \\
\text { farklı gruplarının } \\
\text { etiketlerine } \\
\text { atıfta bulunur. }\end{array}$ & $\begin{array}{l}\text { 1-Asit baz reaksiyonları denge reaksiyonlarıdır. } \\
\text { 2-Vücudumuz çok iyi bir tampon çözeltidir. Su amfoter } \\
\text { özellik gösterir. } \\
\text { 3-Asit ve baz kavramı organik kimyanın temelini oluş- } \\
\text { turur. Asit ve baz için birçok tanım yapılmıştır. }\end{array}$ & 52 \\
\hline Neden/Öncüllük ilişkisi & $\begin{array}{l}\text { Nedensel bir } \\
\text { etki, bir } \\
\text { değişiklik veya } \\
\text { sıralı bir işleme } \\
\text { atıfta bulunur. }\end{array}$ & $\begin{array}{l}\text { 1-Bir eşdeğer gram asit ile bir eşdeğer gram bazın reak- } \\
\text { siyona girerek tuz ve su oluşturması sırasında açığa çı- } \\
\text { kan ısıya nötralleşme ısısı denir. } \\
\text { 2-Renksiz bir reaksiyona indikatör eklediğimizde çö- } \\
\text { zelti renklenir. } \\
\text { 3-Genellikle asit baz tepkimelerinde nötralleşme tepki- } \\
\text { meleri tampon çözelti oluşturabilir. }\end{array}$ & 53 \\
\hline Analoji ilişkisi & $\begin{array}{l}\text { Mantıksal karşı- } \\
\text { laştırmalara atıfta } \\
\text { bulunur }\end{array}$ & $\begin{array}{l}\text { 1-Amfoter tür tabiri caiz ise adamına göre muamele ya- } \\
\text { pan maddedir. } \\
\text { 2-Amfoter türler aslında gerçek hayatta iki yüzlü insan- } \\
\text { lara benzerler. } \\
\text { 3-Asit ve bazlar birbirlerinden çok hoşlanmışlar ve so- } \\
\text { nucunda çocukları tuz meydana gelmiş. Asitlik ve baz- } \\
\text { lıkları o kadar kuvvetliymiş ki anne ve babaları sadece }\end{array}$ & 5 \\
\hline
\end{tabular}




\begin{tabular}{|c|c|c|}
\hline & & $\begin{array}{l}\text { indikatör görevi görmüştür. Yani tepkimeyi etkileme- } \\
\text { mişlerdir. Fakat babaları iki türlü oynamıştır. Hem asit } \\
\text { gibi hem baz gibi. }\end{array}$ \\
\hline Karakteristik ilişki & $\begin{array}{l}\text { Özelliklere, farklı } \\
\text { yönlere, detay- } \\
\text { lara, niteliklere } \\
\text { veya bir nesne- } \\
\text { nin, işlem, kav- } \\
\text { ram ya da fikrin } \\
\text { kullanışlilığına } \\
\text { atıfta bulunur. }\end{array}$ & $\begin{array}{l}\text { 1-Asitlik ve bazlık pH metre ile ölçülür. } \\
0-14 \text { arasında değerlendirilirler. } \\
\text { 2-H+ iyonunu kolay veren maddelere } \\
\text { güçlü asit, OH- iyonunu kolay veren } \\
\text { maddelere güçlü baz diyebiliriz. } \\
\text { 3-Tampon çözeltiler yapacağımız bir } \\
\text { deneyde çözeltinin pH'ının değişme- } \\
\text { mesi için kullandığımız çözeltilerdir. }\end{array}$ \\
\hline Kanıt ilişkisi & $\begin{array}{l}\text { Delillere, verilere, } \\
\text { desteklere, kanıt- } \\
\text { lara, belgelere, } \\
\text { önlemlere veya } \\
\text { bir nesne, fikir, } \\
\text { süreç veya kavra- } \\
\text { min doğrulanma- } \\
\text { sina, onayına } \\
\text { atıfta bulunur. }\end{array}$ & $\begin{array}{l}\text { 1-Asitlerin kuvvetlerine } \\
\text { pka'larına veya molekül veril- } \\
\text { mişse rezonansına, elektrone- } \\
\text { gatifliğine, indiktüf etki vb. et- } \\
\text { kenlere bakarak karar verebi- } \\
\text { liriz. } \\
\text { 2-Tepkimede madde tüketi- } \\
\text { mini gözlemlemek için indi- } \\
\text { katör kullanılır. } \\
\text { 3-Asit baz reaksiyonlarında } \\
\text { dönüm noktalarını veya } \\
\text { pH'ın nötr olduğu noktayı } \\
\text { bulabilmek için yardımcı ola- } \\
\text { rakindikatörler kullanılır. }\end{array}$ \\
\hline
\end{tabular}

Tablo 8'e göre öğrencilerin yazdıkları paragraflarda yer alan cümlelerin içerdiği ilişkilendirmelerin yapısal karakteristik bakımından en fazla "Karakteristik ilişki" ve "Neden/öncüllük ilişkisi" kategorisi ile uyumlu olduğu tespit edildi. "Karakteristik ilişki" kategorisinde öğrencilerin daha çok kavramların özellikleri, farklı yönleri, nitelikleri ve kavramın kullanışlılığı hakkında bilgi verdiği, "Neden/öncüllük ilişkisi” kategorisinde kavramlar hakkında nedensel bir etki, bir değişiklik veya sıralı bir işleme atıfta bulunduğu görüldü. Kimya öğretmeni adaylarına ait karakteristik ilişkinin tipik örnekleri aşağıdaki öğrenci ifadelerinde görülmektedir:

"İndikatörlerin seçimi asit veya bazın pH arahı̆ına göre seçilir." (K4)

"Asitlik kuvvet sıralaması eşlenik bazın kararlnlğ̆ına göre belirlenebilir." (K1)

"Tampon çözeltiler yapacă̆ımı bir deneyde çözeltinin pH'ınm değişmemesi için kullandı̆̆ımız

çözeltilerdir." (K27)

Neden-öncüllük ilişkisinin tipik örnekleri ise aşağıdaki öğrenci ifadelerinde görülmektedir:

"Tuz = Asit ile bazm reaksiyonlarndan meydana gelen katılardır." (K8)

"İndikatör ortamın $p H$ durumuna göre renk değiştirir." (K5) 
"Renksiz bir reaksiyona indikatör eklediğimizde çözelti renklenir." (K16)

Tablo 8'e göre öğrencilerin yazdıkları paragraflarda yer alan cümlelerin içerdiği ilişkilendirmelerin en az "Analoji ilişkisi" kategorisi ile uyumlu olduğu, bu kategoride öğrencilerden sadece 5 'inin kavramlar ile analoji ilişkisi kurduğu tespit edildi. Analoji ilişkisi kuran öğrencilerin daha çok kavramlar ile ilgili mantıksal karşılaştırmalara atıfta bulunduğu görülmüştür. Analoji ilişkisinin tipik örnekleri ise aşağıdaki öğrenci ifadelerinde görülmektedir:

"Amfoter tür tabiri caiz ise adamina göre muamele yapan maddedir. " (K12)

"Amfoter türler aslinda gerçek hayatta iki yüzlü insanlara benzerler. " (K7)

"Asit ve bazlar birbirlerinden çok hoşlanmışlar ve sonucunda çocukları tuz meydana gelmiş. Asitlik ve bazlikları o kadar kuvvetliymiş ki anne ve babaları sadece indikatör görevi görmüştür. Yani tepkimeyi etkilememişlerdir. Fakat babaları iki türlü oynamıştır. Hem asit gibi hem baz gibi. " (K22)

\section{Tartışma ve Sonuç}

Genel amacı kimya öğretmeni adaylarının asit-baz konu alanıyla ilgili bilişsel yapılarının belirlenmesi olan bu araştırmanın araştırma sorusu "Kimya öğretmeni adaylarının asit-baz konu alanıyla ilgili bilişsel yapılarının betimsel ve yapısal özellikleri nasıldır?" şeklindeydi.

Kimya öğretmeni adaylarının asit-baz konu alanıyla ilgili bilişsel yapı haritalarındaki organizasyonunun genel olarak uyarıc kelimeden cevap kelimeye doğru tek yönlü ilişkilendirmeler içeren, hiçbir çift yönlü ve çapraz ilişkinin söz konusu olmadığı, statik bir yapıda olduğu tespit edildi. Bilişsel yapida beliren kavramlardan sadece bir tane cevap kelimenin (Lewis asit baz) farklı uyarıcı kelimelerle (asit, baz) ilişkilendirildiği gözlendi.

Bu çalışmada KİT'te yer alan her bir uyarıcı kelimeye karşılık yazılan geçerli, farklı cevap kelimelerin sayısı belirlenerek ilave nitel bulgulara ulaşıldı (Tablo 7). Hiçbir ilişkilendirme içermeyen bir kavramın bilişsel yapıda anlamı yoktur ve bilişsel yapıda o kavramla ilgili ilişkilendirmeler yapılandıkça o kavramın bilişsel yapıdaki anlamı gelişir. Daha fazla ilişkilendirme içeren uyarıcı kelimenin bilişsel yapıdaki anlamı daha zengindir (Bahar vd., 1999; Derman ve Eilks, 2016). Buna göre kimya öğretmeni adaylarının asit-baz konu alanıyla ilgili bilişsel yapılarında, uyarıı kelimelerle ilişkilendirilen farklı cevap kelime sayısı bakımından [Bazlık (71), Asitlik (70), Asit (66), Baz 
(57), Tuz (48), Nötralleşme (36), İndikatör (48), pH (55), Tampon Çözelti (43), Konjuge asit-baz (32), Amfoter tür (17)] “Tuz, Nötralleşme, İndikatör, Tampon çözelti, Amfoter tür ve Konjuge asit baz" kavramlarının güçlü ve zengin bir biçimde anlamlandıramazken; "Bazlık, Asitlik, Asit, Baz, pH" kavramlarının diğer kavramlara göre nispeten daha zengin bir biçimde anlamlandırıldığını belirtebiliriz.

Kimya öğretmeni adaylarının asit-baz konu alanıyla ilgili bilişsel yapılarında yer alan ilişkilendirmelerin yapısal karakteristik bakımından; Parçası/bölümü ilişkisi (44), örnek/çeşit ilişkisi (52), neden/öncüllük ilişkisi (53), analoji ilişkisi (5), karakteristik ilişki (78), kanıt ilişkisi (27) kategorilerinde çeşitlendiği, ilişkilendirmelerin karakteristik ilişki ve neden/öncüllük ilişkisi kategorisinde yoğunlaştı̆̆ görülmektedir (Tablo 8). Bu sonuçlar bize kimya öğretmeni adaylarının asit-baz konu alanıyla ilgili bilişsel yapılarında yer alan kavramlar arasındaki ilişkilerin yapısal karakteristiklerinin tanıtıcı/nedensel bilgi düzeyinde yoğunlaştığını göstermektedir.

Kimya öğretmeni adaylarının cevap kelimelerinden ve kavramlararası ilişkilendirmelerinin yapısal karakteristiklerinden yola çıkarak farklı asit-baz tanımlarını, bu tanımların aralarındaki farkı, sundukları kavramsal açıklamalar bakımından birbirlerine göre üstünlüklerini ve eksikliklerini anlamlandıracak şekilde bağlamsal olarak kavramsallaştıramadıklarını bunun yerine daha çok ezberleyerek öğrendiklerini söyleyebiliriz.

$\mathrm{Bu}$ çalışmada elde edilen bulgular ve ulaşılan sonuçlar doğrultusunda, kimya öğretmeni eğitimcilerinin, öğrencilerin asit-baz konu alanıla ilgili çift yönlü, çapraz ve güçlü ilişkilendirmeler içeren dinamik ve zengin bir bilişsel yapı organizasyonu geliştirebilmelerini desteklemek için özenle tasarlanmış öğretim materyalleri ve aktivitelerini (deneyler, animasyonlar, simülasyonlar gibi kimya bilgisinin makroskobik, moleküler ve atomik boyutunun kullantmını içeren görselleştirmeler) öğrencilerin öğretim düzeylerine uygun olarak kullanmaları veya daha etkin bir biçimde kullanmaya devam etmeleri gerekir (Derman ve Eilks, 2016). Talanquer (2011)' e göre bu öğretim tasarımlarında kimyanın farklı boyut (oluşum/yapı, enerji, zaman) ve yaklaşımlarının da (matematiksel, kavramsal, bağlamsal, tarihsel) göz önünde bulundurması tavsiye edilebilir. Kimya öğretmeni eğitimcileri farklı asit-baz tanımlarını öğretirken bu tanımların birbiriyle ilişkisini, sundukları kavramsal açıklamalar bakımından birbirlerine göre üstünlüklerini ve eksikliklerini ortaya koyan 
bağlamsal bir içerik kullanmaya özen göstermelidirler. Bu noktada kimya öğretmeni eğitimcileri asit-baz konu alanı ile ilgili öğretimlerinde tutarlı bir biçimde tanecik boyutuna dayalı açıklamalara (Eilks, 2013), uygun modeller ve similasyon, animasyon gibi gösterimleri kullanmaya odaklanmalıdır. Kimya öğretmeni eğitimcileri bu tip materyalleri seçerken internet kaynaklarında bulunabilecek potansiyel riskleri ve yanıltıc faktörleri göz önünde bulundurmalıdırlar (Eilks, Witteck ve Pietzner, 2009; 2012).

Bu çalışmada, bilişsel yapıları belirlemede KİT'lerin doğasından kaynaklanan sinırlılıkla mücadele etmek ve kimya öğretmeni adaylarının asit-baz konu alanıyla ilgili bilişsel yapılarının betimsel ve yapısal özelliklerini belirlemek için KİT ve SYT kombine olarak kullanıldı. Bilişsel yapılarla ilgili olarak gerçekleştirilecek kimya eğitimi araştırmalarında KİT' lerinin SYT , kavram haritaları veya mülakatlarla kombine olarak kullanılması önerilebilir. 


\title{
EXTENDED ABSTRACT
}

\section{Prospective Chemistry Teachers'Cognitive Structure Related To Asit-Base Domain}

\author{
$*$ \\ Figen Güneş - Ayşegül Derman \\ Necmettin Erbakan Üniversitesi
}

This study aims to determine the descriptive and structural features of the cognitive structures of prospective chemistry teachers' related to the acidbase subject domain. This research, which is a case study, was structured in two phases. In the first phase of this study, it was aimed to analyze the direction and strength of the concepts and the inter-conceptual relations in students' cognitive structures related to the acid-base subject domain. In the second phase it was aimed to determine the structural features of the inter-conceptual relationships in students' cognitive structures related to the acid-base subject domain in a detailed and holistic way.

This research is a case study in terms of describing the cognitive structures of prospective chemistry teachers related to the acid-base subject domain in a detailed and descriptive way and explaining the events, which are assumed to be causal connection among the emerging structures (Yin, 1984; cited in: Subaşı and Okumuş, 2017). In this study, the cognitive structures of prospective chemistry teachers related to the acid-base subject domain were regarded as the situation examined.

This research was conducted with prospective chemistry teachers who continued their education in the 2018-2019 academic year. A total of 29 prospective chemistry teachers participating in the study continue their undergraduate and graduate studies at a public university, which is located in a provincial center in Central Anatolia. Among these, 13 of them are undergraduate 3 rd grade, 10 are undergraduate 4 th grade and the remaining 6 are graduate students. Students enrolled in the chemistry teaching program with close or similar scores.

Although the word-association test is quite effective in determining the concepts in students' cognitive structures and their frequency, strength and direction; It has some limitations in terms of determining the nature of the 
relations between concepts (structural elements of cognitive structures) (Nakipoğlu, 2008). In this study, in order to overcome this limitation arising from the structure of the word-association test and determine the descriptive and structural features of students' cognitive structures related to the acid-base subject domain in a detailed and holistic manner, by considering the suggestions in the related studies (Derman and Ebenezer, 2018; Derman and Eilks, 2016; Nakipoğlu 2008), word-association test and free writing technique were used together. Moreover, this case can also be regarded as a mechanism that increases the reliability of the study since it provides triangulation in terms of data collection technique. Content analysis technique was used to analyze the data.

In this study, 10 different frequency ranges were determined while forming cognitive structure maps of students. In the cognitive structures of prospective chemistry teachers related to the acid-base subject domain, it was observed that five stimulus words appeared as separate cells only in the frequency range of $11 \leq f \leq 20$, which is the first level. It was observed that with the response words "litmus paper, household cleaning agents, conjugated acid, red litmus litmus, sour, Lewis acid base and $\mathrm{H}+$ " of the word "acid", the word "Lewis acid base, $\mathrm{NaOH}$, bitter, $\mathrm{OH}$-, conjugated base" and blue litmus with stimulant words, "salt" stimulant word "Acid + Base $\rightarrow$ Salt and $\mathrm{NaCl}$ " response words, "indicator" stimulant word "titration" response word and "amphoter type" stimulus word "acid versus base" response word appeared as separated cells through one-way associations. At this level, it was determined that of the response words; the word "acid" was associated with seven, the word "base" with the six, the word "salt" with two of them, while the word "indicator" and the word "amphoter type" was associated with a single response word. Although all associations at this level are one-sided, it was observed that the same response word (Lewis acid base) was associated with different stimulus words (acid, base). This level is the most advanced level in terms of organization of cognitive structure compared to other levels because of the low frequency values of the associations $(11 \leq f) 20)$, yet the strength of the associations is weak.

In this research, in addition to the above findings, additional qualitative findings were reached by determining the number of valid, different response words, which were written for each stimulus word. A concept without 
any association has no meaning in the cognitive structure, and as the association about that concept are made in the cognitive structure, the meaning of that concept in the cognitive structure develops. The meaning of the stimulus word with more associations in the cognitive structure is richer (Bahar et al., 1999; Derman \& Eilks, 2016). In this case, we determined that in terms of the number of different response words associated with stimulus words in the cognitive structures of the prospective chemistry teachers related to the acidbase subject domain [Basicity (71), Acidity (70), Acid (66), Base (57), Salt (48), Neutralization (36), Indicator (48), $\mathrm{pH}$ (55), Buffer Solution (43), Conjugated acid-base (32), Amphoter species (17)] The concepts of "Basicity, Acidity, Acid, Base, $\mathrm{pH}^{\prime \prime}$ are interpreted richer than other concepts.

It was observed that in terms of structural characteristics, inter-conceptual associations in the cognitive structures of prospective chemistry teachers related to the acid-base subject domain diversified in the categories of; Part / section relationship (44), sample / variety relationship (52), cause / precedence relationship (53), analogy relationship (5), characteristic relationship (78), evidence relationship (27)and the associations concentrated in the category of cause/precedence relationship and characteristic relationship .

It has been determined that the organization of the cognitive structures of the prospective chemistry teachers related to the acid-base subject domain is generally in a static structure that includes one-way associations from stimulus word to response word. It was observed that one response word (Lewis acid base) was associated with different stimulus words (acid, base). It was determined that the cognitive structure organization in the frequency range (First level-11 $\leq \mathrm{f} \leq 20$ ), where the strength of the associations was the weakest, was the most advanced level compared to other levels of the organization. It was observed that the structural characteristics of the inter-conceptual associations of the prospective chemistry teachers related to the acid-base subject domain were mostly concentrated in the relationship categories of "Part / department relationship (44), sample / variety relationship (52), cause / precedence relationship (53)". The obtained findings were discussed in detail by comparing them with the relevant studies and some inferences were made. Based on the findings, specific suggestions were offered to chemistry teacher educators for the teaching of the acid-base subject domain. 


\section{Kaynakça / References}

Abraham, M. R., Williamson, V. M. ve Westbrook, S. L. (1994). A cross-age study of the anderstanding five concepts. J. Res. Sci. Teach, 31, 147-165.

Adadan, E., Trundle, K. C. ve Irving, K. E. (2010). Exploring grade 11 students' conceptual pathways of the particulate nature of matter in the context of multirepresentational instruction. J. Res. Sci. Teach, 47, 1004-1035.

Adadan, E. ve Savasci, F. (2012). An analysis of 16-17-year-old students' understanding of solution chemistry concepts using a two-tier diagnostic instrument. Int. J. Sci. Educ., 34, 513-544.

Adadan, E. (2014). Investigating the influence of preservice chemistry teachers' understanding of the particle nature of matter on their conceptual understandings of solution chemistry. Chem. Educ. Res. Pract, 15, 219-238.

Arslan, M. (2007). Eğitimde yapılandırmacı yaklaşımlar. Ankara Üniversitesi Eğitim Bilimleri Fakültesi Dergisi, 1 (40), 41-61.

Ayas, A. ve Çepni, S. (2011). Kuramdan uygulamaya fen ve teknoloji öğretimi (13. bs.). Ankara: Pegem Akademi.

Bahar, M., Johnstone, A. H. ve Sutcliffe, R. G. (1999). Investigation of students' cognitive structure in elementary genetics through word association tests. J. Biol. Educ, 33, 134-141.

Bahar M. ve Hansell M. H. (2000). The relationship between some psychological factors and their effect on the performance of grid questions and word association tests. Educ. Psychol., 20, 349-364.

Blake, A. J. ve Norland, F. H. (1978). Science instruction and cognitive growth in college students. J. Res. Sci. Teach., 15, 413-419.

Büyüköztürk, Ş., Kilıç Çakmak, E., Akgün, Ö. E., Karadeniz, Ş. ve Demirel, F. (2016). Bilimsel araştırma yöntemleri (23. Bs.). Ankara: Pegem Akademi.

Calp, M. (2013). Turkey serbest ve yaratıcı yazma tekniğine göre oluş̧urulan kompozisyonların yazılı anlatımın niteliği ve puanlama tekniği açısından karşılaştrilması. International Periodical For The Languages, Literature and History of Turkish or Turkic, 8(9), 879-898.

Creswell, j. W. (2016). Nitel araştırma yöntemleri (3. Bs.). Ankara: Siyasal Kitabevi.

Çalık, M. (2005). A cross-age study of different perspectives in solution chemistry from junior to senior high school. Int. J. Sci. Math. Educ., 3, 671-696.

Çalık, M., Ayas, A. ve Coll, R. K. (2007). Enhancing pre-service primary teachers' conceptual understanding of solution chemistry with conceptual change text. Int. J. Sci. Math. Educ., 5, 1-28. 
Derman, A., ve Eilks, I. (2016). Using a word association test for the assessment of high school students' cognitive structures on dissolution. Chemistry Education Research and Practice, 17(4), 902-913.

Derman, A. ve Ebenezer, J. (2018). The effect of multiple representations of physical and chemical changes on the development of primary pre-service teachers cognitive structures. Research in Science Education, 48, 1-27.

Doğan, S., Yücel Güngör, M. ve Güngör, O. (2018). Turizm meslek yüksekokulu öğrencilerinin sosyal medyaya yönelik bilişsel yapılarının kelime ilişkilendirme testi aracılı̆ıyla incelenmesi. Turizm Akademik Dergisi, 5 (1), 166-176.

Ebenezer, J. V. ve Gaskel, P. J. (1995). Relational conceptual change in solution chemistry. Science Education, 79(1), 1-17.

Ebenezer, J. V. (2001). A hypermedia environment to explore and negotiate students' conceptions: animation of the solution process of table salt. J. Sci. Educ. Technol., 10, 73-91.

Elden, M. (2003). Hedef kitle davranışlarını etkileyen psikolojik bir faktör olarak öğrenme: öğrenme ve reklam ilişkisi. Gazi Üniversitesi Illetişim Fakültesi Dergisi, $18,1-29$.

Ercan, F., Taşdere, A. ve Ercan, N. (2010). Kelime ilişkilendirme testi aracilğı̆yla bilişsel yapının ve kavramsal değişimin gözlenmesi. Türk Fen Eğitimi Dergisi, 7 (2), 136-154.

Erim, A. ve Yöndem, S. (2009). Video model destekli öğretimin gitar performansına etkisi. Dokuz Eylül Üniversitesi Buca Eğitim Fakültesi Dergisi, 26, 45-55.

Gunstone, F. R. (1980). Word association and the description of cognitive structure. Research in Science Education, 10, 45-53.

Jensen, E. (2006). Teaching with the brain in mind, turkish edition (Trans. A. Doğanay). Adana: Nobel Kitabevi.

Köseoğlu, F. ve Bayır, E. (2011). Examining cognitive structures of chemistry teacher candidates about gravimetric analysis through word association test method. Trakya Üniversitesi Eğitim Fakültesi Dergisi, 1(1), 107-125.

Kurt, H. ve Ekici, G. (2013). Biyoloji öğretmen adaylarının bağımsız kelime ilişkilendirme testi ve çizme-yazma tekniğiyle "osmoz" kavramı konusundaki bilişsel yapılarınun belirlenmesi. International Periodical For The Languages, Literature and History of Turkish or Turkic, 8(12), 809-829.

Kurt, H. ve Ekici, G. (2013a). Biyoloji öğretmen adaylarınn "bakteri” konusundaki bilişsel yapılarının ve alternatif kavramlarının belirlenmesi. Turkish StudiesInternational Periodical For The Languages, Literature and History of Turkish or Turkic, 8(8), 885-910. 
Liu, X. ve Ebenezer, J. (2002). Descriptive categories and structural characteristics of students' conceptions: an exploration of the relationship. Research In Science And Technological Education, 20(1), 111 -132.

Liu, X. ve Lesniak, K., (2005), Students' progression of understanding the matter concept from elementary to high school. Sci. Educ., 89, 433-450.

MEB. (2018). Ortaöğretim kimya dersi (9, 10, 11 ve 12. Sinfflar) öğretim programı. 24 Haziran 2019 tarihinde http://mufredat.meb.gov.tr/ProgramDetay.aspx?PID $=350$ adresinden erişildi.

Miles, M. B. veHuberman A. M. (1994). Qualitative data analysis: an expanded sourcebook. Thousend Oaks: Sage.

Nakipoğlu, C. (2008). Using word associations for assessing non major science students' knowledge structure before and after general chemistry instruction: the case of atomic structure. Chem. Educ. Res. Pract., 9, 309-322.

Othman, J., Treagust, D. F. ve Chandrasegaran, A. L. (2008). An investigation into the relationship between students' conceptions of the particulate nature of matter and their understanding of chemical bonding. Int. J. Sci. Educ., 30, 15311550.

Paas, F. ve Ayres, P. (2014). Cognitive load theory: a broader view on the role of memory in learning and education. Educ Psychol Rev., 26, 191-195.

Schizas, D., Katrana, E., ve Stamou, G. (2013). Introducing network analysis into science education: methodological research examining secondary school students' understanding of 'decomposition'. International Journal Of Environmental And Science Education, 8(1), 175-198.

Schunk, D., H. (2009). Learning theories, turkish edition (Editor: M. Şahin), Ankara: Nobel Yayın Dağıtım.

Shavelson, R. J., (1972), Some aspects of the correspondence between content structure and cognitive structure in physics instruction. J. Educ. Psychol., 63, 225234.

Sinan, O., Yıldırım, O., Kocakülah, M. S. ve Aydın, H. (2006). Fen bilgisi öğretmen adaylarınin proteinler, enzimler ve protein sentezi ile ilgili kavram yanılgları. Gazi Eğitim Fakültesi Dergisi, 26(1), 1-16

Stavridou, H. ve Solomonidou, C. (1989). Physical phenomenachemical phenomena: do pupils make distinction? Int. J. Sci. Educ., 11, 83-92.

Subaşı, M. ve Okumuş, K. (2017). Bir araştırma yöntemi olarak durum çalışması. Atatürk Üniversitesi Sosyal Bilimler Enstitüsü Dergisi, 21(2), 419-426.

Taber, K. S. (2008). Conceptual resources for learning science: issues of transience and grain-size in cognition and cognitive structure. Int. J. Sci. Educ., 30, 1027-1053. 
Tavukçuoğlu, E. (2018). Lise öğrencilerinin sürtünme kuvveti, ivme ve eylemsizlik kavramlarıla ilgili bilişsel yapılarnnın araşttrılması. (Yüksek lisans tezi). Hacettepe Üniversitesi Eğitim Bilimleri Enstitüsü, Ankara.

Tsai, C. C. (2001), Proping students' cognitive structures in science: the use of a flow map method coupled with a meta listening technique. Stud. Educ. Eval., 27, 257-268.

Tyson, L.M., Venville, G.J., Harrison, A.G. ve Treagust, D.F. (1997). A multidimensional framework for interpreting conceptual change events in the classroom. Science Education, 81, 387-404.

Uzuntiryaki, E. ve Geban, O. (2005). Effect of conceptual change approach accompanied with concept mapping on understanding of solution concepts. Instr. Sci., 33, 311-339.

Wilson, J. M. (1990). Chemistry concepts and group cognitive structure: a study of undergraduate nursing students. Research In Science Education, 20, 292-299.

\section{Kaynakça Bilgisi / Citation Information}

Derman, F. ve Güneş, F. (2020). Kimya öğretmeni adaylarının asit-baz konu alanıyla ilgili bilişsel yapıları. OPUS-Uluslararası Toplum Araştırmaları Dergisi, 16(Eğitim ve Toplum Özel Sayıs1), 5884-5910. DOI: 10.26466/opus.800862 